\title{
Is urban bushmeat trade in Colombia really insignificant?
}

\author{
Nathalievan Vliet, Maria Quiceno, Jessica Moreno, Daniel Cruz \\ Julia E. FA and RoBert NASI
}

\begin{abstract}
The bushmeat trade in ecosystems in South America other than those within the Amazon basin is presumed to be insignificant, as alternative sources of protein (e.g. beef, chicken, fish) are considered to be more readily available in non-moist forests. However, studies and confiscation reports from countries such as Colombia suggest that bushmeat is consumed in a variety of ecosystems, although the nature of market chains, particularly in urban areas, is still unknown. We studied the urban bushmeat trade in markets in the five main ecoregions in Colombia. We recorded a total of 85 species, the most frequently traded being the paca Cuniculus paca, red brocket deer Mazama americana, grey brocket deer Mazama gouazoubira, capybara Hydrochoerus hydrochaeris, armadillo Dasypus spp. and black agouti Dasyprocta fuliginosa. Most sales of wild meat occur through clandestine channels and involve a limited number of stakeholders. Bushmeat is a luxury product in urban areas of the Caribbean, the Pacific and the Andean regions. Further work is needed to quantify and monitor the volumes of bushmeat traded, comprehend motivations, explore ways of reducing threats, and engage with stakeholders to organize legal and sustainable use of bushmeat.
\end{abstract}

Keywords Bushmeat, Colombia, market chain, mountain forest, trade, tropical dry forest, tropical moist forest, urban areas

To view supplementary material for this article, please visit http://dx.doi.org/10.1017/So030605315001118.

\section{Introduction}

T $\mathrm{n}$ South America use of wildlife as food or gifts is deeply 1 embedded in traditional rural lifestyles. An estimated 5-8 million people throughout the continent are thought to consume bushmeat regularly, as a source of protein, fat

Nathalie van Vliet (Corresponding author) and Robert Nasi Center for International Forestry Research (CIFOR), Bogor 16115, Indonesia

E-mail vanvlietnathalie@yahoo.com

Maria Quinceno, Jessica Moreno and Daniel Cruz Fundación S.I. Science International, Cundinamarca, Colombia

Julia E. FA Division of Biology and Conservation Ecology, School of Science and the Environment, Manchester Metropolitan University, Manchester, UK, and CIFOR, Bogor, Indonesia

Received 25 June 2015. Revision requested 29 July 2015.

Accepted 26 August 2015. First published online 4 March 2016. and micronutrients (Sirén \& Machoa, 2008; Golden et al., 2011), and most of those who rely on bushmeat are among the poorest in the region (Rushton et al., 2005). In some cases bushmeat is also eaten as a festival food or because people prefer it over domestic meat (Wilkie \& Godoy, 2001; Sirén, 2012). The bushmeat trade is an important part of local economies, contributing to livelihoods, food security and dietary diversity (Sirén, 2012; Parry et al., 2014; van Vliet et al., 2014). In most South American countries trading of bushmeat can be conducted legally under licenses issued by local authorities (van Vliet et al., 2015b); however, because administrative procedures to obtain a permit are often unclear or complex, most of the bushmeat trade is carried out illegally.

Data on bushmeat sold in South American towns are largely derived from confiscations by environmental agencies (OTCA, 2009), and therefore may underestimate the situation. Some information exists on the extent of urban bushmeat markets in Iquitos in Peru (Rushton et al., 2005), Pompeya in Ecuador (WCS, 2007) and Abaetetuba in Brazil (Baía et al., 2010). Parry et al. (2014) examined the scale and drivers of urban consumption of wildlife in the forested pre-frontier of Brazilian Amazonia and found that almost half of the urban households surveyed consumed bushmeat at least once per month. In a study of the species and volume of bushmeat sold in the trifrontier (Brazil-Peru-Colombia) Amazonian towns of Leticia, Tabatinga and Caballococha, van Vliet et al. (2014) showed that an estimated $473 \mathrm{t}$ of bushmeat was potentially traded per year. Given the size of the urban population of this region it is likely that $3.2 \mathrm{~kg}$ per capita per year is consumed there, which is comparable to the estimated consumption for urban areas in Central Africa, where bushmeat consumption is commonplace (Nasi et al., 2011).

The literature on bushmeat trade in South America has focused primarily on the Amazon region, probably because the bushmeat trade in other ecosystems, such as tropical dry forests, mountain forests or savannahs, is thought to be insignificant and largely absent because of the greater availability of alternative sources of protein (e.g. beef, chicken, fish; Rushton et al., 2005). It is estimated that only c. 1.5$2.0 \%$ of the total population in South America consume bushmeat regularly (Rushton et al., 2005), and bushmeat consumption is considered to be absent in urban areas.

A number of studies have highlighted the importance of wildlife in various regions in Colombia (see Vargas-Tovar, 2012, for a review). Despite the existence of sanctions 
(including imprisonment), commercial hunting is a regular occurrence within rural communities there; for example, an estimated $43 \%$ of animals taken by hunters in Puerto Nariño (an Amazon region on the border with Peru) were sold to consumers (Quiceno et al., 2014). The majority of species traded were mammals ( $60 \%$ of reports), followed by birds $(26 \%)$ and reptiles (14\%). Hunting was carried out essentially for subsistence, as a direct source of food or as a means of generating income to purchase commercially available foodstuffs and beverages, processed products, or hunting supplies. In Inírida (Colombian Amazonas bordering Venezuela) $31-53 \%$ of hunter offtake was sold (Ortega, 2014). In the Andes region, however, commercial hunting in Boyacá was found to be relatively insignificant (CasasRamírez, 2007) but sometimes rodents and birds were sold to meet shortfalls in agricultural production.

Countrywide data on bushmeat trade in Colombia are available from official sources. Data from the Department of Security indicate that as much as $31,147 \mathrm{~kg}$ of bushmeat was confiscated during 1998-2004 (Mancera \& Reyes, 2008), and data from the Direction of Taxes and Customs show that c. 12,621 kg of capybara meat Hydrochoerus hydrochaeris was seized during 2004-2006 (Mancera \& Reyes, 2008). These data are presumed to significantly underestimate the amounts traded, as seizures probably account for only $1-10 \%$ of the volume of wild meat commercialized (Mancera \& Reyes, 2008). There is therefore a need to understand better which species are commercialized for meat, what bushmeat trade chains exist, and the trade routes and stakeholders involved, to identify ways of making bushmeat trade sustainable without threatening Colombia's biodiversity.

We investigated wild meat markets in a number of contrasting environments in Colombia, in 24 urban municipalities within the country's five main ecoregions. We aimed to document the wild species sold for meat in various parts of the country by visiting known trade establishments (markets, stalls, stores, butchers, restaurants) in the urban areas targeted. Although our approach was intended to be a rapid assessment, it enabled us to determine the extent of the bushmeat trade in this ecologically varied country.

\section{Study area}

Colombia is a megadiverse country, hosting almost $10 \%$ of global biodiversity (Carrizosa-Umaña, 2014). Its primary terrestrial biomes have undergone several changes: $53 \%$ of the mainland is still covered with natural forests, which host more than half of the terrestrial animals and plants and account for more than two-thirds of terrestrial net primary production (IDEAM et al., 2007). One of the most threatened forest ecosystems is the dry forest, which covers c. $2 \%$ of its original area. The Amazon and Andean regions have the highest numbers of plant species, followed by the Pacific, the Caribbean and the Orinoquía regions (Carrizosa-Umaña, 2014). Colombia's biodiversity is not only important for the country's natural heritage and the preservation of unique species, it is also essential for guaranteeing basic conditions for the improvement of human welfare, social equality and economic development. Moreover, biodiversity and its functions and processes provide direct-use goods and services, such as food, medicines, fuel, wood and water, and indirect-use services, such as climate regulation, prevention of natural disasters, soil formation, water purification and recreation.

We sampled 24 small and medium-sized towns (5,000150,000 inhabitants) in five ecoregions (Table 1): Caribbean, Andean, Pacific, Orinoquía and Amazon (Fig. 1). Our intention was to target urban areas that still have a clear connection with rural processes and products, and we included a market in the capital city, Bogota, for comparison. Our study covered two of the three main biomes (tropical dry forest and tropical moist forest) and six territorial environmental systems (of the 19 described in Colombia by Carrizosa-Umaña, 2014).

Colombia has a history of conflict, and some regions pose high risks for researchers, particularly in areas where illicit drug trafficking and illegal mining are carried out (PNUD, 2011). Security is therefore an important criterion in identifying appropriate locations for field research. Given that we were studying an illegal activity, we were particularly careful to avoid unnecessary risks for our research team.

\section{Methods}

The study was carried out in September 2013 in Leticia, and during November 2014-January 2015 at the other sites. We deployed three research teams, each comprising two people, who were trained to apply the methodology consistently. Each team conducted fieldwork in one or two ecoregions, spending 15-20 days at each site. We used a snowball strategy, asking the first person we contacted to provide us with names of other people in town selling bushmeat. We did this until no new contacts were referred to us. We visited a total of 528 sale points that might potentially sell bushmeat, including markets, restaurants, butcher shops, fish markets, food stalls and grocery stores (Table 2). We used participant observation, visited sale points and source areas regularly, and conducted informal discussions (in Spanish) with stakeholders. After the first visit and at an appropriate moment, to avoid mistrust, we explained the objectives of the study to stakeholders. Some stakeholders ( $3 \%$ of those approached) did not want to share information but most were interested in the motives of our research and contributed with interest to the study. We spent time discussing the use of wild meat with the various stakeholders, sometimes 
TABLE 1 The study areas in five ecoregions of Colombia (Fig. 1), with the main biomes represented, territorial environmental systems, river basins, human population, and area.

\begin{tabular}{|c|c|c|c|c|c|}
\hline Study area & $\begin{array}{l}\text { Main biomes } \\
\text { (IDEAM et al., } \\
\text { 2007) }\end{array}$ & $\begin{array}{l}\text { Territorial environ- } \\
\text { mental systems } \\
\text { (Carrizosa-Umaña, } \\
\text { 2014) }\end{array}$ & $\begin{array}{l}\text { River basins } \\
\text { (Salazar-Holguín, 2013) }\end{array}$ & No. of inhabitants & Area $\left(\mathrm{km}^{2}\right)$ \\
\hline \multicolumn{6}{|c|}{ Amazonian region } \\
\hline Inírida & \multirow{4}{*}{$\begin{array}{l}\text { Tropical moist } \\
\text { forest }\end{array}$} & \multirow{4}{*}{$\begin{array}{l}\text { The Amazon and } \\
\text { Orinoco forest }\end{array}$} & Orinoco basin & 15,676 & 17,000 \\
\hline Leticia & & & Amazon basin & 37,832 & 109.6 \\
\hline Puerto Nariño & & & Amazon basin & 6,983 & 1,800 \\
\hline Andean region & & & & & \\
\hline Bogotá & \multirow{5}{*}{$\begin{array}{l}\text { Tropical dry forest, } \\
\text { tropical moist } \\
\text { forest }\end{array}$} & \multirow{5}{*}{$\begin{array}{l}\text { The Central System } \\
\text { The Coffee West }\end{array}$} & Magdalena-Cauca basin & $6,763.33$ & 1,775 \\
\hline Salento & & & Magdalena-Cauca basin & 7,001 & 378 \\
\hline Circasia & & & Magdalena-Cauca basin & 26,705 & 91 \\
\hline Calarcá & & & Magdalena-Cauca basin & 75,628 & 219 \\
\hline Montenegro & & & Magdalena-Cauca basin & 38,714 & 149 \\
\hline \multicolumn{6}{|c|}{ Orinoquia region } \\
\hline Yopal & \multirow{9}{*}{$\begin{array}{l}\text { Tropical moist } \\
\text { forest }\end{array}$} & \multirow{9}{*}{$\begin{array}{l}\text { The piedmont plains } \\
\text { and the Orinoco } \\
\text { flood }\end{array}$} & Orinoco basin & 103,754 & 2,771 \\
\hline Villanueva & & & Orinoco basin & 20,730 & 825 \\
\hline Monterrey & & & Orinoco basin & 11,421 & 879 \\
\hline Tauramena & & & Orinoco basin & 15,699 & 2,607 \\
\hline Aguazul & & & Orinoco basin & 33,172 & 148 \\
\hline Pore & & & Orinoco basin & 7,490 & 780 \\
\hline Paz de Ariporo & & & Orinoco basin & 26,915 & 13,800 \\
\hline Hato Corozal & & & Orinoco basin & 9,618 & 5,518 \\
\hline \multicolumn{4}{|c|}{ Caribbean region } & & \\
\hline Aracataca & \multirow{7}{*}{$\begin{array}{l}\text { Tropical dry forest, } \\
\text { tropical moist } \\
\text { forest }\end{array}$} & \multirow{5}{*}{$\begin{array}{l}\text { The Sierra Nevada de } \\
\text { Santa Marta and its } \\
\text { watershed }\end{array}$} & Magdalena-Cauca basin & 34,929 & 1,755 \\
\hline Santa Marta & & & Magdalena-Cauca basin & 414,387 & 2,393 \\
\hline Zona Bananera & & & Magdalena-Cauca basin & 56,404 & 479 \\
\hline Fundación & & & Magdalena-Cauca basin & 56,107 & 931 \\
\hline Ciénaga & & & $\begin{array}{l}\text { Caribbean basin, } \\
\text { Magdalena-Cauca basin }\end{array}$ & 100,908 & 1,212 \\
\hline El Copey & & & Magdalena-Cauca basin & 24,368 & 968 \\
\hline Pacific region & & & & & \\
\hline Quibdó & $\begin{array}{l}\text { Tropical moist } \\
\text { forest }\end{array}$ & The Pacific Coast & Caribbean basin & 109,121 & 3,337 \\
\hline
\end{tabular}

sharing a meal and conversing about their favourite meals. Conversations followed an unstructured format but were guided by questions such as: Is any bushmeat sold here? Do people here like it? Where does it come from? Who brings it here? How much control is there around here? What is the price of bushmeat? Which species are sold most often? Who buys the bushmeat? With the help of the stakeholders we mapped trade routes to estimate the catchment area offering meat to the town. We asked about the list of species sold at every site we visited.

\section{Results}

Sale points and stakeholders Bushmeat was sold in all of the municipalities we visited. All sales detected were clandestine, hidden from the general public. Trade occurred within a trusted network of customers and sellers. A total of 139 of the 528 sale points visited traded wild meat (Table 2): 10 markets, 48 restaurants, three butchers, 44 non-food stalls, 22 food stalls, six grocery stores, and six sale points scattered within peri-urban areas. Women acted as intermediaries in the bushmeat trade, selling wild meat to complement their primary commercial activity (such as selling fish, domestic meats or groceries). Hunters sold their quarry directly to known consumers, took the meat to the local market, or disembarked it onto riverine harbours from where it was sold to urban restaurants or end consumers. Bushmeat was often kept hidden. A total of 193 hunters were known to participate in the market chain in the five ecoregions. Hunters supplying meat to towns were usually farmers of diverse origins (colonos, Afro-descendants or indigenous people) who hunted as part of a diversified economy on their own private lands or communal grounds. However, in the Pacific and Amazon regions we identified and interviewed peri-urban hunters who worked in rural (e.g. farming or timber extraction) and urban situations (e.g. transporters, carpenters) but relied on the bushmeat trade to supplement their income. 


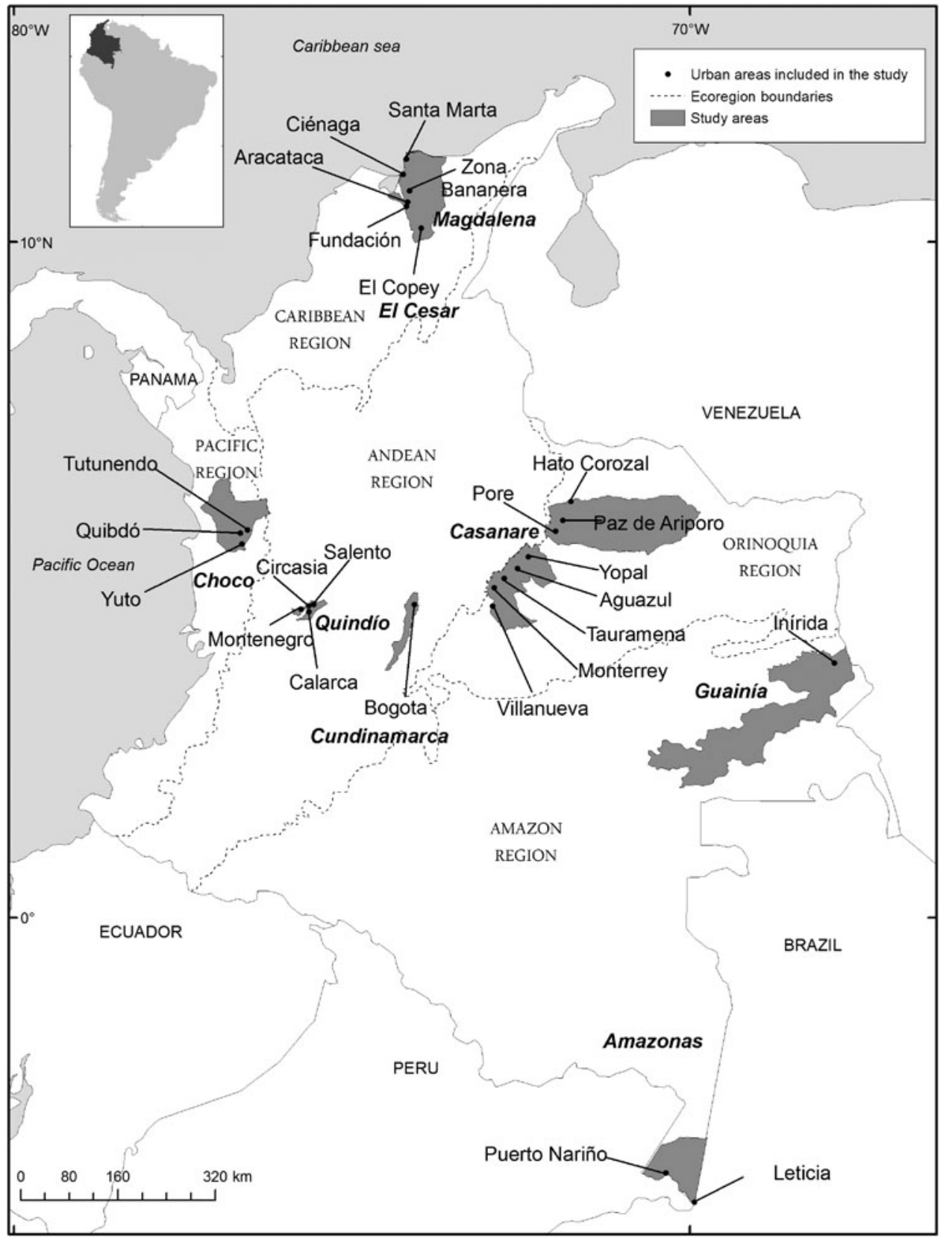

FIG. 1 Distribution of the study sites in five ecoregions of Colombia.
For these people the sale of bushmeat was a highly lucrative activity, and some had the means to invest the equivalent of USD 1,200 in trained hunting dogs. Most hunters were men, although women and children also hunted small animals, such as rodents and birds, but only for their own consumption. The market chain is based on trust between hunters, intermediaries and consumers, who are in contact by phone or regular visits (Fig. 2), and trading usually occurs in the early morning, before dawn. Market chains have adapted to the level of law enforcement in each region.

Traded species In total, 85 species were traded in the five ecoregions studied (Supplementary Table S1). The proportion of each species sold at various locations is shown in
Fig. 3. In the Amazon region 20 species were traded, and the most commonly traded species were the paca Cuniculus paca, grey brocket deer Mazama gouazoubira, red brocket deer Mazama americana, lowland tapir Tapirus terrestris and white-lipped peccary Tayassu pecari. In the Andean region 19 species were traded, most commonly the capybara, armadillo, pacarana Dinomys branickii, rabbit Sylvilagus brasiliensis and black agouti Dasyprocta fuliginosa. In Bogota, capybara, paca, armadillo, wild duck and pigeon were the most frequently traded species. In the Orinoquía region there was a distinct preference for capybara (dried or fresh); other commonly traded species included armadillo, paca and white-tailed deer Odocoileus virginianus. In the Caribbean region 14 species were 
TABLE 2 Places where bushmeat was sold in the urban and peri-urban areas visited, with number of places visited (and number of these with bushmeat on sale).

\begin{tabular}{|c|c|c|c|c|c|c|c|}
\hline Municipality & Market place & Restaurants & Butchers & Street sellers & Food stalls & Grocery & $\begin{array}{l}\text { Indigenous communities } \\
\text { \& rural settlements }\end{array}$ \\
\hline \multicolumn{8}{|c|}{ Amazonian region } \\
\hline Inírida & $1(0)$ & $12(4)$ & $9(0)$ & $0(0)$ & $14(3)$ & $1(0)$ & $0(0)$ \\
\hline Leticia & $1(1)$ & $16(13)$ & $0(0)$ & $0(0)$ & $14(14)$ & $0(0)$ & $0(0)$ \\
\hline Puerto Nariño & $1(1)$ & $9(9)$ & $0(0)$ & $0(0)$ & $12(0)$ & $0(0)$ & $0(0)$ \\
\hline \multicolumn{8}{|l|}{ Andean region } \\
\hline Bogotá & $13(2)$ & $2(0)$ & $0(0)$ & $6(4)$ & $0(0)$ & $0(0)$ & $0(0)$ \\
\hline Salento & $0(0)$ & $7(0)$ & $0(0)$ & $0(0)$ & $0(0)$ & $0(0)$ & $0(0)$ \\
\hline Circasia & $1(0)$ & $6(1)$ & $187(0)$ & $0(0)$ & $0(0)$ & $0(0)$ & $0(0)$ \\
\hline Calarcá & $1(0)$ & $8(0)$ & $1(0)$ & $0(0)$ & $0(0)$ & $0(0)$ & $0(0)$ \\
\hline Montenegro & $1(0)$ & $3(0)$ & $4(0)$ & $0(0)$ & $0(0)$ & $0(0)$ & $0(0)$ \\
\hline \multicolumn{8}{|c|}{ Orinoquia region } \\
\hline Yopal & $1(1)$ & $75(1)$ & $1(1)$ & $0(0)$ & $0(0)$ & $1(1)$ & $0(0)$ \\
\hline Villanueva & $1(0)$ & $15(1)$ & $1(1)$ & $0(0)$ & $0(0)$ & $0(0)$ & $0(0)$ \\
\hline Monterrey & $1(0)$ & $15(2)$ & $1(1)$ & $0(0)$ & $0(0)$ & $0(0)$ & $0(0)$ \\
\hline Tauramena & $0(0)$ & $10(0)$ & $2(0)$ & $0(0)$ & $0(0)$ & $0(0)$ & $0(0)$ \\
\hline Aguazul & $1(0)$ & $16(0)$ & $0(0)$ & $0(0)$ & $0(0)$ & $1(1)$ & $0(0)$ \\
\hline Pore & $1(0)$ & $11(0)$ & $0(0)$ & $0(0)$ & $0(0)$ & $1(1)$ & $0(0)$ \\
\hline Paz de Ariporo & $1(1)$ & $35(1)$ & $0(0)$ & $0(0)$ & $0(0)$ & $0(0)$ & $0(0)$ \\
\hline Hato Corozal & $0(0)$ & $6(0)$ & $0(0)$ & $0(0)$ & $0(0)$ & $0(0)$ & $0(0)$ \\
\hline \multicolumn{8}{|c|}{ Caribbean region } \\
\hline Aracataca & $1(1)$ & $0(0)$ & $0(0)$ & $0(0)$ & $0(0)$ & $0(0)$ & $1(1)$ \\
\hline Santa Marta & $1(1)$ & $0(0)$ & $0(0)$ & $0(0)$ & $12(0)$ & $0(0)$ & $0(0)$ \\
\hline Zona Bananera & $0(0)$ & $7(1)$ & $0(0)$ & $0(0)$ & $0(0)$ & $2(0)$ & $0(0)$ \\
\hline Fundación & $2(0)$ & $7(5)$ & $8(0)$ & $0(0)$ & $15(3)$ & $4(3)$ & $2(2)$ \\
\hline Ciénaga & $1(0)$ & $2(1)$ & $0(0)$ & $0(0)$ & $0(0)$ & $1(0)$ & $0(0)$ \\
\hline El Copey & $1(1)$ & $8(2)$ & $0(0)$ & $0(0)$ & $0(0)$ & $0(0)$ & $0(0)$ \\
\hline Algarrobo & $0(0)$ & $3(0)$ & $0(0)$ & $0(0)$ & $0(0)$ & $0(0)$ & $0(0)$ \\
\hline \multicolumn{8}{|l|}{ Pacific region } \\
\hline Quibdó & $3(1)$ & $22(7)$ & $19(0)$ & $40(40)$ & $2(2)$ & $0(0)$ & $11(8)$ \\
\hline Total & $34(10)$ & $295(48)$ & $64(3)$ & $46(44)$ & $69(22)$ & $11(6)$ & $14(11)$ \\
\hline
\end{tabular}



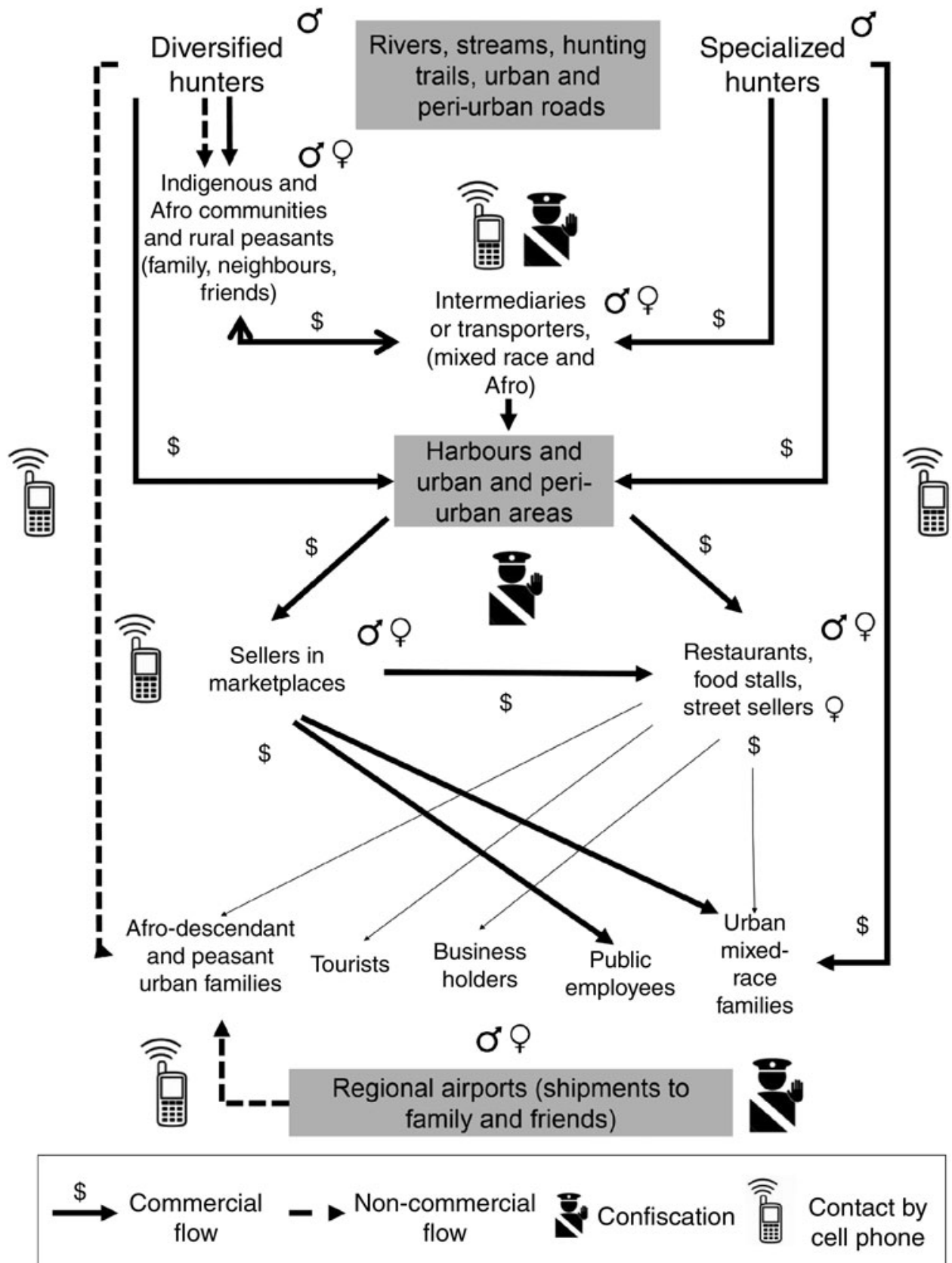

FIG. 2 The basic structure of the bushmeat commodity chain in Colombia. reportedly traded, mainly paca, deer (red and grey brocket), black agouti and armadillo. In the Pacific region 28 species were traded, the most common being paca, followed by black agouti, armadillo, red and grey brocket deer, caiman and river turtles.

Trade routes In all regions except Bogota we observed short trade routes from rural areas to nearby towns. The distance between a town and its most remote source area was rarely $>150 \mathrm{~km}$ (c. $80 \mathrm{~km}$ in the Caribbean, usually $<90 \mathrm{~km}$ in the Amazon, and $100-150 \mathrm{~km}$ in the Orinoquía and Pacific regions). We observed no established longer routes towards the capital or to other countries, except for transboundary trade in the case of Leticia. Bogota is a special case, as bushmeat enters the city from remote places (from the Caribbean, Andean, Orinoquía or Amazon regions) but in small quantities and on a sporadic basis. Bushmeat is transported to the main urban centres via rivers and peri-urban and urban roads, using a variety of transport, including boats, motorcycles, bicycles, cars, public buses, mules and trucks.

Prices Bushmeat was the most expensive meat available in towns in the Caribbean, Pacific and Andean regions. In the Amazon, bushmeat was cheaper than beef but more 

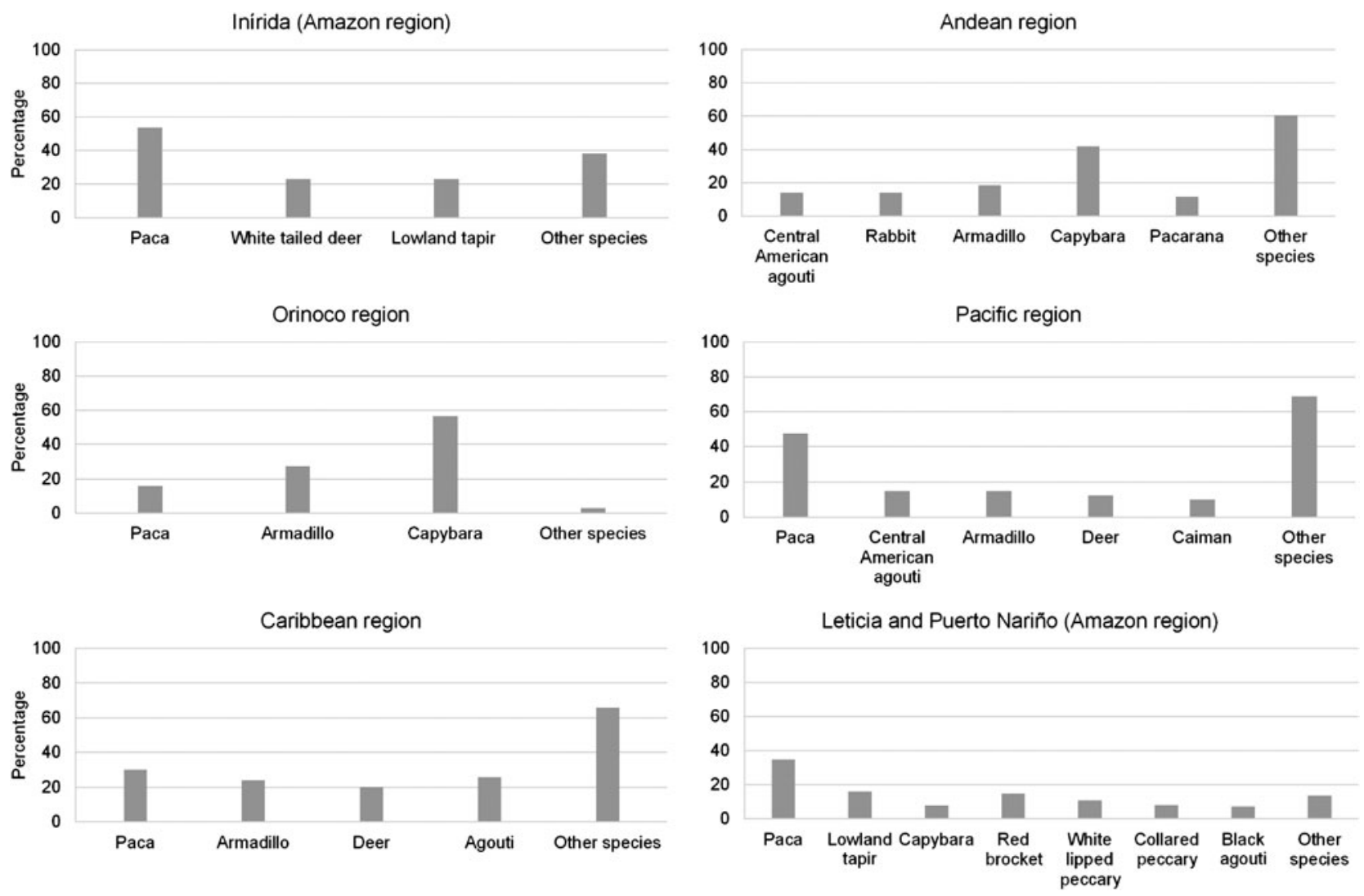

FIG. 3 Proportions of various species sold as bushmeat at six study sites within five ecoregions in Colombia (Fig. 1).

TABLE 3 Prices of bushmeat and other sources of animal protein (USD kg ${ }^{-1}$ ) in five ecoregions of Colombia (Fig. 1).

\begin{tabular}{lllllll}
\hline Region & & & \multicolumn{3}{c}{ Fresh goat } \\
meat & Fresh fish & Canned sardines \\
\hline Amazonian & Fresh bushmeat & Fresh beef & Fresh chicken & 1.78 & 3.16 & 1.38 \\
Andean & 4.80 & 5.33 & 5.53 & 2.79 & & 3.48 \\
Orinoquia & 4.93 & 3.91 & 3.48 & 3.95 & 6.08 \\
Caribbean & 7.13 & 3.75 & 1.78 & & 5.07 \\
Pacific & 10.40 & 4.74 & 2.61 & & 58 \\
\hline
\end{tabular}

expensive than most fish, chicken and canned meats. In the Orinoquía region bushmeat was less expensive than fish but more expensive than beef (Table 3). According to stakeholders' perceptions, prices depend on the availability of the resource, the intensity of law enforcement and the purchasing power of consumers. In rural and peri-urban areas around the study sites bushmeat was considered a cheap option as individuals hunted for their own consumption and occasional sale. However, in urban areas bushmeat is considered a luxury for which customers are willing to pay a premium price because of its special taste or as an alternative to beef, pork and chicken. In the Amazon, for example, beef costs USD $5 \mathrm{~kg}^{-1}$, industrial chicken USD $2.5 \mathrm{~kg}^{-1}$, and fresh bushmeat USD $4 \mathrm{~kg}^{-1}$ on average; in contrast, in the Andean and Pacific regions beef costs USD $4.7 \mathrm{~kg}^{-1}$ on average and fresh paca meat can retail for as much as USD $11.8 \mathrm{~kg}^{-1}$.

\section{Discussion}

We found evidence of bushmeat trade in towns in a range of ecoregions in Colombia. Despite regulations and law enforcement efforts bushmeat continues to be traded illegally by means of well-established, clandestine routes. This finding contrasts with the suggestion by Rushton et al. (2005) that bushmeat may no longer be consumed in urban areas in Latin America because of the availability of other cheaper sources of protein. Unlike bushmeat markets in Central 
Africa (Starkey, 2004; Fa et al., 2006; Nasi et al., 2011; Dupain et al., 2012; van Vliet et al., 2014) or some markets in the Brazilian Amazon (Baía et al., 2010; Parry et al., 2014; van Vliet et al., 2015a) where bushmeat is sold openly, the trade in Colombia occurs clandestinely, although the stakeholders involved in the trade and the structure of the trade chain have similar characteristics to those observed in most Central and West African markets (Cowlishaw et al., 2005). In Colombia, as in Central and West Africa, the main stakeholders in the trade chain are farmer hunters, commercial hunters, wholesalers, market traders and food stall operators. However, there are some differences: (1) In Colombia both men and women are involved in the trade, whereas in West and Central Africa the trade is conducted mainly by women. (2) In Colombia all traders have another primary occupation (they sell other food products, groceries or clothes, or have another source of income) and sell bushmeat to supplement their income. In Central and West Africa, market and food stall traders commonly specialize in bushmeat trade. (3) Most bushmeat is sold fresh or frozen in Colombia, whereas in West and Central African markets (except in Gabon) and in Brazil (van Vliet et al., 2015a) bushmeat is most often sold smoked (Cowlishaw et al., 2005; van Vliet et al., 2014). (4) The number of stakeholders involved in the trade in Colombia is limited compared with Central Africa, and the trade occurs within a network of known consumers and a limited number of providers. In Leticia, for example, only two traders sell wild meat in the local market (van Vliet et al., 2015a), compared with a town such as Koulamoutou (Gabon), with a similar population size, which may have c. 13 traders operating in the market (Starkey, 2004). (5) In Bogota it is possible to find bushmeat but there is no organized regular market chain supplying the city, as observed in many cities in Central Africa. The trade remains concentrated in medium-sized towns close to source areas.

At our study sites, hunters come from rural or peri-urban areas and sell bushmeat as part of a diversified economy. Farmer hunters hunt for subsistence on private or community land, where they also practise agriculture and sell their surplus to known consumers or to wholesalers. Peri-urban hunters hunt mainly for commercial purposes but hunting is not their primary occupation. They often combine hunting and other rural livelihood activities (e.g. timber extraction) with small urban businesses or salaried jobs, as also observed in Brazil (van Vliet et al., 2015a). In urban areas in the Caribbean, Pacific and Andean regions, bushmeat is the most expensive type of meat available and the trade is lucrative, giving peri-urban hunters the means to invest in hunting for commercial purposes. As observed in some urban areas of Africa (Wilkie et al., 2005; Fa et al., 2006; Kümpel et al., 2007; Brashares et al., 2011; van Vliet \& Mbazza, 2011; Bachand et al., 2015; but also see some exceptions, e.g. van Vliet et al., 2014), bushmeat is a luxury for wealthy families and is consumed despite being among the most expensive meats, whereas the opposite is true in more remote areas, where bushmeat continues to be among the cheapest available source of protein, provided there is a hunter in the family. In areas where bushmeat is less common (e.g. the Andean region) it can cost three times more than beef. As urban markets grow and rural areas are increasingly connected to them, it is possible that less bushmeat is kept for individual consumption and more is sold to the urban luxury market, which has implications for rural food security, as observed in Madagascar (Golden et al., 2011). In Brazil also, Parry et al. (2014) found evidence of a long-term transition from bushmeat as an economical source of protein for the poor to a luxury food for the wealthy.

The majority of species traded in Colombia are categorized as Least Concern on the IUCN Red List, and paca, black agouti, red and grey brocket deer, capybara and caiman are not categorized as threatened on Colombia's national Red List (IAvH, 2015). However, the white-lipped peccary is categorized as Vulnerable, the giant armadillo as Endangered, and the lowland tapir and white-tailed deer as Critically Endangered on the national Red List. Most of the markets in our study are therefore far from a post-depletion sustainability situation such as that observed in the Takoradi market in Ghana (Cowlishaw et al., 2005), where only the more resilient species persist. For all our study sites, the trade of threatened species therefore warrants closer attention.

Bushmeat trade routes in Colombia are relatively short $(\leq 150 \mathrm{~km})$ and do not imply inter-regional or international trade (except for transboundary trade across border rivers in the Amazon). This is important for two reasons: (1) The possibility that the trade in bushmeat and the handling of fresh meat could contribute to the emergence of zoonotic pandemics, as observed in Africa, is limited. (2) The bushmeat trade involves a limited number of stakeholders operating in a small geographical area, which facilitates the development of programmes to target all levels of the trade (consumers, traders and hunters), with strategies that can be adapted to each of these levels, combining sensitization, legal sustainable trade, enforcement strategies and monitoring.

\section{Acknowledgements}

We thank all the stakeholders who agreed to participate in this research. We are grateful to the Instituto de Investigaciones Ambientales del Pacífico, the Instituto Alexander von Humboldt and Fundación Omacha for their support. This work was funded by USAID and UKAID through the Bushmeat Research Initiative of the Center for International Forestry Research. 


\section{References}

Bachand, N., Arsenault, J. \& Ravel, A. (2015) Urban household meat consumption patterns in Gabon, central Africa, with a focus on bushmeat. Human Dimensions of Wildlife: An International Journal, 20, 147-158.

Baía, Jr, P.C., Guimarães, D.A. \& Le Pendu, Y. (2010) Non-legalized commerce in game meat in the Brazilian Amazon: a case study. Revista de Biología Tropical, 58, 1079-1088.

Brashares, J.S., Golden, C.D., Weinbaum, K.Z., Barrett, C.B. \& OKello, G.V. (2011) Economic and geographic drivers of wildlife consumption in rural Africa. Proceedings of the National Academy of Sciences of the United States of America, 108, 13931-13936.

Carrizosa-Umaña, J. (2014) Colombia Compleja. Jardín Botánico de Bogotá José Celestino Mutis. Instituto de Investigación de Recursos Biológicos Alexander von Humboldt, Bogotá, Colombia.

Casas-Ramírez, R.A. (2007) Patrones de Uso de la Fauna Silvestre por Parte de la Población Asentada en las Veredas Alejandría, Cardozo y la Libertad (San Eduardo, Boyacá, Colombia). Facultad de Ciencias, Escuela de Biología, Universidad Pedagógica y Tecnológica de Colombia, Tunja, Boyacá, Colombia.

Cowlishaw, G., Mendelson, S. \& Rowcliffe, J.M. (2005) Structure and operation of a bushmeat commodity chain in southwestern Ghana. Conservation Biology, 19, 139-149.

Dupain, J., Nackoney, J., Vargas, J.M., Johnson, P.J., Farfán, M.A., Bofaso, M. \& FA, J.E. (2012) Bushmeat characteristics vary with catchment conditions in a Congo market. Biological Conservation, 146, 32-40.

Fa, J.E., Seymour, S., Dupain, J., Amin, R., Albrechtsen, L. \& Macdonald, D.W. (2006) Getting to grips with the magnitude of exploitation: bushmeat in the Cross-Sanaga rivers region, Nigeria and Cameroon. Biological Conservation, 129, 497-510.

Golden, C.D., Fernald, L.C.H., Brashares, J.S., Rasolofoniaina, B.J.R. \& Kremen, C. (2011) Benefits of wildlife consumption to child nutrition in a biodiversity hotspot. Proceedings of the National Academy of Sciences of the United States of America, 108, 19653-19656.

IAvH (Instituto Alexander von Humboldt) (2015) SIBSistema de Información Sobre Biodiversidad de Colombia. Http:// www.sibcolombia.net/web/sib/acerca-del-sib [accessed March 2015].

IDE A M, IGAC, IAvH, INvemar, I. Sinchi \& IIAP (2007) Ecosistemas Continentales, Costeros y Marinos de Colombia. Instituto de Hidrología, Meteorología y Estudios Ambientales, Instituto Geográfico Agustín Codazzi, Instituto de Investigación de Recursos Biológicos Alexander von Humboldt, Instituto de Investigaciones Ambientales del Pacífico Jhon von Neumann, Instituto de Investigaciones Marinas y Costeras José Benito Vives De Andréis e Instituto Amazónico de Investigaciones Científicas Sinchi, Bogotá, Colombia.

Kümpel, N.F., East, T., Keylock, N., Rowcliffe, J.M., Cowlishaw, G. \& Milner-Gulland, E.J. (2007) Determinants of bushmeat consumption and trade in continental Equatorial Guinea: an urban-rural comparison. In Bushmeat and Livelihoods: Wildlife Management and Poverty Reduction (eds G. Davies \& D. Brown), pp. 73-91. Blackwell Publishing, Oxford, UK.

Mancera, N. \& Reyes, O. (2008) Comercio de fauna silvestre en Colombia. Revista Facultad de Agronomía de la Universidad Nacional Medellín, 61, 4618-4645.

Nasi, R., Taber, A. \& van Vliet, N. (2011) Empty forests, empty stomachs? Bushmeat and livelihoods in the Congo and Amazon Basins. International Forestry Review, 13, 355-368.

ORTEGA, M.C.R. (2014) Ecological sustainability of mammal hunting in Inírida region, Colombian Amazon. MSc thesis. Universidad Nacional de Colombia, Bogotá, Colombia.
OTCA (Organización del Tratado de Cooperación A MAZÓNICA) (2009) Monitoreo y control del tráfico de fauna y flora en la Amazonia. Primer informe de avance. Proyecto ATN/ OC-9251-RG. OTCA, Brasilia, Brazil.

Parry, L., Barlow, J. \& Pereira, H. (2014) Wildlife harvest and consumption in Amazonia's urbanized wilderness. Conservation Letters, 7, 565-574.

PNUD (Programa de las Naciones Unidas para el Desarrollo) (2011) El Campesinado: Reconocimiento para Construir País. Cuaderno del Informe Nacional de Desarrollo Humano, Bogotá, Colombia.

Quiceno, M.P., Cruz-Antia, D., Moreno, J. \& van Vliet, N. (2014) Descripción de la cacería y consumo de carne de monte en el río Loretoyacu y el lago Tarapoto, Puerto Nariño-Amazonas, Colombia. In Los Humedales de Tarapoto Aportes al Conocimiento sobre su Biodiversidad y Uso (eds F. Trujillo \& S. Duque), pp. 294321. Fundación Omacha, Bogotá, Colombia.

Rushton, J., Viscarra, R., Viscarra, C., Basset, F., Baptista, R. \& Brown, D. (2005) How Important is Bushmeat Consumption in South America: Now and in the Future? Overseas Development Institute, London, UK.

Salazar-Holguín, F. (2013) Zonificación Hidrográfica Preliminar de Colombia. Instituto de Hidrología, Meteorología y Estudios Ambientales (IDEAM), Bogotá, Colombia. Http://www.arcgis.com/ home/item.html?id=103b63dcc9f448acbd63f22b728b1ao2 [accessed March 2015].

Sirén, A.H. (2012) Festival hunting by the Kichwa people in the Ecuadorean Amazon. Journal of Ethnobiology, 32, 30-50.

Sirén, A. \& MACHOA, J. (2008) Fish, wildlife, and human nutrition in tropical forests: a fat gap? Interciencia, 33, 186-193.

STARKEY, M.P. (2004) Commerce and subsistence: the hunting, sale and consumption of bushmeat in Gabon. $\mathrm{PhD}$ thesis. University of Cambridge, Cambridge, UK.

van Vliet, N., Cruz, D., Quiceno-Mesa, M.P., Neves de Aquino, L.J., Moreno, J., Ribeiro, R. \& FA, J.E. (2015a) Ride, shoot, and call: wildlife use among contemporary urban hunters in Três Fronteiras, Brazilian Amazon. Ecology and Society, 20, 8.

van Vliet, N., Gomez, J., Quiceno-Mesa, M.P., Escobar, J.F., Andrade, G. \& Nasi, R. (2015b) Sustainable wildlife management and legal commercial use of bushmeat in Colombia: the resource remains at the crossroads. International Forestry Review, 17, 438-447.

VAN Vliet, N. \& MbazZa, P. (2011) Recognizing the multiple reasons for bushmeat consumption in urban areas: a necessary step toward the sustainable use of wildlife for food in Central Africa. Human Dimensions of Wildlife, 16, 45-54.

van Vliet, N., Quiceno-Mesa, M.P., Cruz-Antia, D., Neves de Aquino, L.J., Moreno, J. \& Nasi, R. (2014) The uncovered volumes of bushmeat commercialized in the Amazonian trifrontier between Colombia, Peru \& Brazil. Ethnobiology and Conservation, 3 , http://dx.doi.org/10.15451/ec2014-11-3.7-1-11.

VARgas-Tovar, N. (2012) Carne de monte y seguridad alimentaria: consumo, valor nutricional, relaciones sociales y bienestar humano en Colombia. In Carne de Monte y Seguridad Alimentaria: Bases Técnicas para una Gestión Integral en Colombia (ed. S. Restrepo), pp. 65-87. Instituto de Investigación de Recursos Biológicos Alexander von Humboldt, Bogotá, Colombia.

WCS (Wildlife Conservation Society) (2007) El Tráfico de Carne Silvestre en el Parque Nacional Yasuní: Caracterización de un Mercado Creciente en la Amazonía Norte del Ecuador. Programa Ecuador Boletín No. 2. WCS, Quito, Ecuador. Http://s3.amazonaws. com/WCSResources/file_20110823_035823_ecu_pub_Programa EcuadorBoletin2_2007_oAuB.pdf [accessed July 2014]. 
Wilkie, D.S. \& Godoy, R.A. (2001) Income and price elasticities of bushmeat demand in lowland Amerindian societies. Conservation Biology, 15, 761-769.

Wilkie, D.S., Starkey, M., Abernethy, K., Ntsame Effa, E., Telfer, P. \& Godoy, R. (2005) Role of prices and wealth in consumer demand for bushmeat in Gabon, Central Africa. Conservation Biology, 19, 268-274.

\section{Biographical sketches}

NATH ALIE VAN VLIET's research focuses on the links between wildlife and livelihoods, and she has worked extensively on bushmeat and its role in food security and local economies in Central Africa and South
America. Maria Quiceno's interests lie the management of biodiversity and conservation of natural resources by indigenous communities, farmers and settlers, and she has worked with research institutions and decision makers at national and international levels. JESSICA MORENO is an environmental biologist specializing in participatory monitoring of use and trade of wildlife in the Amazonian trifrontier region and the Casanare department of Colombia. DANIEL CRUZ is an ecologist working on the use of biodiversity, wildlife management, socio-environmental conflicts and cultural change in rural communities. JULIA $F_{A}$ is a conservation scientist whose work focuses on human use of wildlife, threatened species and ex situ conservation. Ro B ERT NASI's research interests include the sustainable use of forest products and the multiple-use management of tropical forests. 